\title{
PKM IBU DAN BALITA STUNTING DI PUSKESMAS PERAWATAN WAAI, KABUPATEN MALUKU TENGAH
}

\author{
Gracia Victoria Souisa $^{1)}$, Zasendy Rehena ${ }^{2)}$, Chriselia Joseph ${ }^{3)}$ \\ Universitas Kristen Indonesia Maluku') \\ Universitas Kristen Indonesia Maluku' \\ Universitas Kristen Indonesia Maluku ${ }^{3)}$ \\ souisagracia@gmail.com
}

\begin{abstract}
ABSTRAK
Dusun Wainuru dan Dusun Ujung Batu merupakan wilayah kerja Puskesmas Perawatan Waai, Kecamatan Salahutu, Kabupaten Maluku Tengah dengan permasalahan stunting yang tinggi. Stunting dapat disebabkan oleh multi faktor seperti angka kecukupan gizi anak, faktor lingkungan dan ekonomi/ pendapatan keluarga. Kesadaran orang tua untuk membawa anak ke Posyandu masih kurang. Akses air bersih, bergantung pada air hujan dan membeli air ketika musim kemarau. Terbatasnya pendapatan masyarakat karena sebagian besar masyarakat berprofesi sebagai nelayan yang bekerja musiman sesuai keadaan cuaca. Jenis tanaman perkebunan hanya berupa tanaman ubi jalar, singkong, pisang yang harganya murah di pasaran. Solusi yang telah dilaksanakan bersama mitra adalah 1). Pemeriksaan air bersih dan hasilnya masih memenuhi persyaratan fisik dan kimia air, namun ada 2 sampel yang belum memenuhi persyaratan mikrobiologi yaitu ditemukan keberadaan E.coli melebihi ambang batas; 2). Pemeriksaan kecacingan menunjukan bahwa dari 26 sampel feses, ada 7 sampel yang positif telur cacing Ascaris lumbricoides. 3). Kegiatan Penyuluhan bagi kader dan ibu rumah tangga tentang stunting dan pengelolaan keuangan keluarga dengan menggunakan metode ceramah dan dialog interaktif. Hasil penyuluhan menunjukan bertambahnya pengetahuan ibu tentang stunting dan pengelolaan keuangan keluarga.
\end{abstract}

Kata Kunci : Puskesmas, Ibu, Balita; Stunting, Desa Waai

\begin{abstract}
Wainuru Hamlet and Ujung Batu Hamlet are the working areas of the Waai Nursing Health Center, Salahutu District, Central Maluku Regency with high stunting problems. Stunting can be caused by multiple factors such as the nutritional adequacy rate of children, environmental factors and the economy / family income. Parents' awareness to bring their children to Posyandu is still lacking. Access to clean water, depend on rainwater and buy water during the dry season. The community's income is limited because most people work as fishermen who work seasonally according to weather conditions. The types of plantation crops are only sweet potato, cassava, and banana, which are cheap in the market. The solutions that have been implemented with partners are 1). The clean water examination and the results still met the physical and chemical requirements of water, however there were 2 samples that did not meet the microbiological requirements, namely the presence of E. coli exceeding the threshold; 2). The worms examination showed that from 26 stool samples, 7 samples were positive for Ascaris lumbricoides eggs. 3). Outreach activities for cadres and housewives about stunting and family financial management using interactive lectures and dialogue methods. The results of the counseling showed an increase in maternal knowledge about stunting and family financial management.
\end{abstract}

Keywords: Puskesmas, Mother, Toddler; Stunting, Waai Village

\section{PENDAHULUAN}

\section{Latar Belakang}

Stunting merupakan penggambaran dari status gizi kurang yang bersifat kronik pada masa pertumbuhan dan perkembangan sejak awal kehidupan. Stunting merupakan manifestasi jangka panjang faktor konsumsi diet berkualitas rendah, penyakit infeksi berulang dan lingkungan. Masa balita merupakan periode yang sangat peka terhadap 
lingkungan sehingga diperlukan perhatian pada kecukupan gizinya. Masalah stunting pada balita dapat menghambat perkembangan anak, seperti penurunan intelektual, rentan terhadap penyakit tidak menular, penurunan produktifitas hingga menyebabkan kemiskinan dan risiko melahirkan bayi dengan berat lahir rendah (Nadiroh, 2015; Kementerin Desa, 2017).

Balita dan baduta yang mengalami stunting akan memiliki tingkat kecerdasan tidak maksimal, menjadikan anak lebih rentan dengan penyakit, dan dimasa depan dapat berisiko pada menurunnya tingkat produktivitas. Pada akhirnya secara luas stunting akan dapat menghambat pertumbuhan ekonomi, meningkatkan kemiskinan dan memperlebar ketimpangan.Anak kerdil yang terjadi di Indonesia tidak hanya dialami oleh rumah tangga/ keluarga yang miskin dan kurang mampu, karena stunting juga dialami oleh rumah tangga/ keluarga yang tidak miskin/ yang berada di atas 40\% tingkat kesejahteraan sosial dan ekonomi (Tim Nasional Percepatan Penanggulangan Kemiskinan, 2017).

Stunting disebabkan oleh faktor multi dimensi dan tidak hanya disebabkan oleh faktor gizi buruk yang dialami oleh ibu hamil maupun anak balita. Beberapa faktor yang menjadi penyebab stunting digambarkan sebagai berikut : (1). Praktek pengasuhan yang kurang baik, termasuk kurangnya pengetahuan ibu mengenai kesehatan dan gizi sebelum dan pada masa kehamilan, serta setelah ibu melahirkan. Penelitian yang dilakukan oleh Mugianti dkk (2018), didapatkan bahwa stunting dapat disebabkan oleh kurangnya pengetahuan keluarga tentang pemenuhan gizi dan terdapat orang tua dengan pendidikan rendah yang diperlukan lintas sector dalam penanganannya. Penelitian lainnya yang dilakukan Ibrahim dan Faramita (2014), menunjukkan bahwa ada hubungan yang signifikan antara tingkat pendidikan ibu ( $p$ $=0,020)$ dan pengetahuan gizi dan stuntimg pada ibu $(p=0,000)$ dengan kejadian stunting anak usia 24 - 59 bulan di wilayah kerja Puskesmas Barombong. (2). Masih terbatasnya layanan kesehatan termasuk layanan ANC - ante natal care (pelayanan kesehatan untuk ibu selama masa kehamilan), post natal care dan pembelajaran dini yang berkualitas. Penelitian yang dilakukan Nadiyah dkk (2014), didapatkan bahwa perlu peningkatan kualitas ante natal care dan kualitas pelayanan kesehatan neonatus dasar berupa penyuluhan tentang menyusui secara eksklusif. Masyarakat Desa Waai masih kurang memanfaatkan layanan kesehatan yang ada. (3). Masih kurangnya akses rumah tangga/ keluarga ke makanan bergizi. Hal ini dikarenakan harga makanan bergizi di Indonesia masih tergolong mahal. penelitian yang dilakukan oleh Aridiyah dkk (2015) menunjukkan bahwa faktor tingkat kecukup zink dan zat besi dapat mempengaruhi terjadinya stunting pada anak balita. Masalah yang terlihat di Desa Waai adalah kurangnya pemanfaatan pekarangan sebagai tempat untuk menanam sayur bagi konsumsi anggota keluarga. Masyakat hanya menanam ubi jalar, singkong dan pisang. Selain itu, pendapatan masyarakat juga terbatas karena profesi nelayan yang bergantung pada cuaca. Penelitian yang dilakukan Setiawan dkk (2018), menunjukkan adanya hubungan antara tingkat pendapatan keluarga dengan stunting. Untuk itu perlu dilakukan 
percontohan pemanfaatan pekarangan sebagai sumber gizi keluarga dengan menanam sayuran seperti katuk, bayam, sawi hijau, daun sup dan tomat. Pekarangan kelurga yang termanfaatkan dengan baik dapat menjadi sumber gizi keluarga, khususnya balita. (Tim Nasional Percepatan Penanggulangan Kemiskinan, 2017). Kurangnya akses ke air bersih dan sanitasi. Data yang diperoleh menunjukan bahwa 1 dari 5 rumah tangga di Indonesia masih buang air besar (BAB) di ruang terbuka, serta 1 dari 3 rumah tangga belum memiliki akses ke air minum bersih. Akses ke air bersih dan jamban juga masih menjadi masalah di Desa Waai (Dusun Wainuru dan Ujung Batu). Sekalipun telah memiliki jamban, masih ada masyarakat yang buang air besar sembarangan di kebun. Penelitian Sutarto (2018), dijelaskan bahwa penting untuk meningkatkan terhadap air bersih dan fasilitas sanitasi serta menjaga kebersihan lingkungan sebagai bentuk pencegahan stunting.

Kurangnya hiegine dan sanitasi juga berkaitan dengan kecacingan. Kecacingan juga merupakan salah satu faktor yang erat dengan kejadian stunting. Kecacingan merupakan penyakit berbasis lingkungan yang dapat menyebabkan menurunnya kondisi kesehatan, gizi, kecerdasan dan produktivitas. Kecacingan pada anak menimbulkan kekurangan gizi yang menetap, dikemudian hari akan menimbulkan dampak pendek menurut umur (Stunting), kurangnya penyerapan nutrisi, anemia, hingga gangguan pertumbuhan pada anak, sehingga penting untuk monitoring kecacingan pada anak (Souisa dkk, 2018). Infeksi kecacingan memberikan pengaruh terhadap status gizi, khususnya yang diakibatkan oleh kelompok cacing soil transmittes helminth (STH) yaitu cacing gelang (Ascaris lumbricoides), cacing cambuk (Trichuris trichiura), dan cacing tambang (Ancylostoma duodenale dan Necator americanus). Anak dengan infeksi cacing akan mengalami malabsorbsi, inflamasi dan penurunan asupan makan karena nafsu makan yang berkurang saat infeksi. Infeksi kecacingan berhubungan dengan turunnya nafsu makan dan asupan makan yang kurang sehingga dapat menyebabkan penurunan kecepatan pertumbuhan, lemahnya kesehatan fisik dan penurunan aktivitas dan lemahnya fungsi kognitif (Febriindari dkk, 2016).

\section{Analisis Situasi}

Puskesmas Perawatan Desa Waai merupakan mitra Program Kemitraan Masyarakat (PKM) yang dikategorikan tidak produktif secara ekonomi/ sosial dengan wilayah kerja mencakup Desa Waai dan Desa Liang. Desa Waai berada di Kecamatan Salahutu dengan jarak dari Universitas Kristen Indonesia Maluku ke Desa Waai adalah $32 \mathrm{~km}$. Berdasarkan data BPS Kecamatan Salahutu (2018), Desa Waai memiliki 4 dusun dan 5 sektor dengan jumlah rumah tangga 1642 dan total jiwa 7465 orang. Desa Waai memiliki sarana kesehatan seperti 1 puskesmas dan 10 posyandu. Lapangan pekerjaan utama dari masyarakat Desa Waai adalah pertanian, kehutanan, perkebunan, perikanan dan peternakan (Badan Pusan Statistik, 2018).

Desa Waai memiliki angka kejadian stunting tertinggi di Kabupaten Maluku Tengah. Angka kejadian stunting di kabupaten Maluku Tengah berdasarkan data sekunder dari Dinas Kesehatan 
Provinsi Maluku mengalami peningkatan pada tahun $2015(21,1 \%)$, tahun 2016 $(23,2 \%)$, tahun $2017(31,4 \%)$, namun menurun pada tahun 2018 dengan angka kejadian 17,8\%. Data Puskesmas Desa Waai menunjukkan bahwa pada triwulan III tahun 2018 dari 573 balita yang di bawa ke Posyandu, sebanyak 47 balita kategori pendek dan 9 balita kategori sangat pendek. Data IV tahun 2018 menunjukkan dari 635 balita yang di bawa ke Posyandu, sebanyak 58 balita kategori pendek dan 8 balita kategori sangat pendek. Sedangkan data tahun 2019 menunjukan jumlah balita pendek sebanyak 59 balita dan 10 balita dengan kategori sangat pendek. Permasalahan stunting di Desa Waai dapat disebabkan oleh beberapa faktor seperti angka kecukupan gizi anak, faktor lingkungan dan ekonomi/ pendapatan keluarga.

Hasil wawancara dengan pemerintah Desa Waai didapatkan gambaran permasalahan yang dialami masyarakat Desa Waai antara lain, terbatasnya pendapatan masyarakat karena sebagian besar masyarakat berprofesi sebagai nelayan yang bekerja musiman sesuai keadaan cuaca. Bila cuaca buruk maka, masyarakat bergantung pada hasil pertanian. Selain itu, jenis tanaman perkebunan hanya berupa tanaman ubi jalar, singkong, pisang yang harganya murah di pasaran. Areal pekarangan keluarga di Desa Waai masih luas namun tidak termanfaatkan dengan baik. Hasil pertanian tahunan seperti cengkeh telah diupayakan masyarakat, namun karena konflik sosial, pohon cengkeh ditebang oleh pihak yang tidak bertanggung jawab. Hasil wawancara dengan kepala puskesmas perawatan Waai, didapatkan informasi bahwa masih ada orang tua yang tidak sadar pentingnya membawa anak ke Posyandu. Informasi lainnya yang diperoleh dari Kepala Puskesmas adalah di Dusun Wainuru dan Dusun Ujung Batu masih kesulitan akses air bersih sehingga hanya bergantung pada air hujan ketika musim hujan dan membeli air ketika musim kemarau. Berdasarkan hasil observasi yang dilakukan oleh tim pengabdian Universitas Kristen Indonesia Maluku (UKIM), pantai di Desa Waai tidak bersih, banyak sampah plastik di pesisir pantai yang berserakan.

Berbagai masalah sosial, ekonomi dan lingkungan yang dihadapi masyarakat Desa Waai, bermuara kepada tingginya angka stunting.

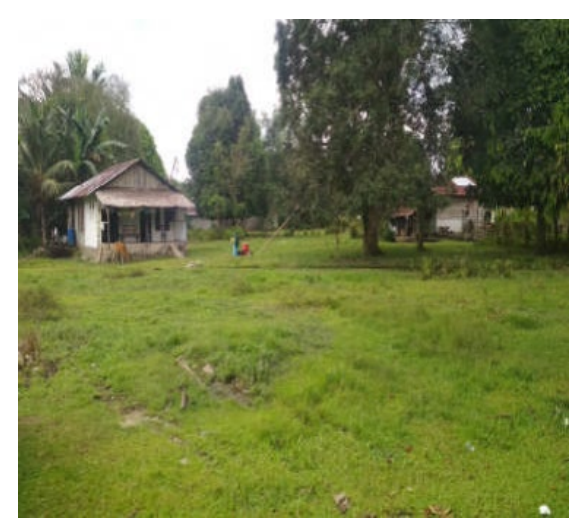

Gambar 1. Pekarangan Rumah

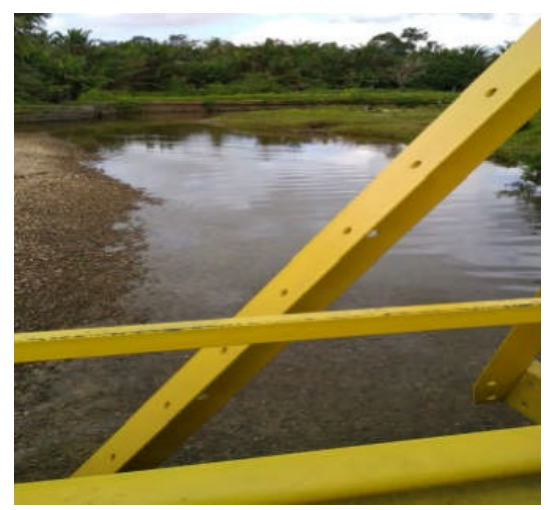

Gambar 2. Sungai sebagai air bersih 
Bertolak dari situasi di atas, maka telah disepakati bersama mitra untuk menerapkan intervensi stunting di Desa Waai melalui kegiatan penyuluhan, pemeriksaan air bersih dan kecacingan. Mitra dalam kegiatan ini adalah Puskesmas Perawatan Waai, yang juga terlibat dalam kegiatan posyandu, sehingga memungkinkan untuk menghimpun ibu balita untuk kegiatan pengabdian.

\section{Permasalahan Pokok Mitra}

Mengacu pada uraian analisis masalah di atas maka prioritas masalah mitra yang telah disepakati melalui proses diskusi (sebanyak 4 kali pertemuan) antara mitra (Puskesmas Perawatan Waai) dan Tim PKM untuk diselesaikan bersama dengan Tim PKM Universitas Kristen Indonesia Maluku adalah

1. Masalah kurangnya pengetahuan ibu balita tentang upaya pencegahan stunting, yang diselesaikan dengan metode penyuluhan untuk meningkatkan pengetahuan ibu balita. Penyuluhan disertai dengan pre dan post test sehingga dapat mengukur peningkatan pengetahuan ibu balita.

2. Masalah sanitasi lingkungan yang meliputi air bersih yang dialami oleh Dusun Wainuru dan Dusun Ujung batu, juga masyarakat Waai pada umumnya yang menggunakan sumber air bersih dari sungai, yang juga digunakan untuk aktivitas mencuci dan mandi. Pendekatan yang disepakati adalah pemeriksaan kualitas air sungai sehingga layak untuk digunakan masyarakat Desa Waai.

3. Masalah kurangnya pengelolaan pendapatan keluarga telah disepakati bersama mitra untuk memberi pelatihan pengisian pembukuan pendapatan keluarga

Masalah prioritas diatas bermuara kepada tingginya angka kejadian stunting di Desa Waai, Kecamatan Salahutu, Kabupaten Maluku Tengah, sehingga penting dilakukan intervensi oleh mitra sesuai dengan kompetensi tim pengabdi.

\section{METODE PELAKSANAAN}

Berdasarkan permasalahan dan solusi yang telah dirumuskan, maka metode pelaksanaan dilakukan dalam beberapa tahapan yaitu tahapan persiapan, tahapan pelaksanaan, tahapan monitoring dan evaluasi serta tahapan pelaporan. Masing - masing tahapan dilaksanakan dengan cermat sesuai dengan 4 prioritas masalah yang akan diselesaikan. Metode pelaksanaan yang telah dilakukan antara lain :

1. Menggunakan metode pemeriksaan laboratorium untuk memastikan kualitas air bersih (fisik dan bakteriologi) yang digunakan masyarakat. Tahapan persiapan meliputi koordinasi dengan laboratorium, pembelian bahan seperti botol sampel, spidol permanen. Selanjutnya print out daftar untuk registasi sampel, atur jadwal dengan mitra. Tahapan pelaksanaan pemeriksaan kualitas air antara lain a). Persiapan 
peralatan sampling; b). pengambilan sampel air sebanyak 6 sampel air; c). mengantar sampel ke Laboratorium Kesehatan Provinsi Maluku; d). Pelaporan hasil, e). diskusi dengan mitra dan pemerintah Desa Waai tentang hasil air bersih. Partisipasi mitra dalam kegiatan ini adalah mengarahkan tim PKM ke sumber air yang digunakan masyarakat. Evaluasi yang dilakukan yaitu membandingkan hasil pemeriksaan kualitas air dengan baku mutu air bersih. Target yang ingin dicapai yaitu adanya hasil pemeriksaan kualitas air bersih (parameter fisik dan bakteriologi). Keberlanjutan program ini adalah adanya peningkatan kesadaran masyarakat untuk menjaga sumber air bersih yang digunakan sehingga menekan kasus stunting pada balita.

2. Menggunakan metode pemeriksaan laboratorium untuk pemeriksaan kecacingan pada balita stunting. Tahapan persiapan meliputi koordinasi dengan laboratorium, pembelian bahan seperti wadah sampel feses, spidol permanen. Selanjutnya print out daftar untuk registasi sampel, atur jadwal dengan mitra. Tahapan pelaksanaan pemeriksaan kecacingan, tahapan yang dilakukan adalah a). persiapan perlengkapan sampling feces dan pelatihan kader posyadu; b). kader memberikan kotak feces kepada orang tua balita stunting dan menanyakan beberapa informasi terkait kebiasaan orang tua balita; c). orang tua balita menyerahkan sampel feces balita kepada kader; d). pemeriksaan dilakukan langsung oleh laboran. Partisipasi mitra dalam kegiatan ini adalah membantu dalam pengambilan sampel feses dan memberikan informasi kebiasaan orang tua balita. Evaluasi yang dilakukan yaitu mengidentifikasi positif atau negatif telur cacing dalam sampel feses. Target yang ingin dicapai yaitu adanya hasil pemeriksaan kecacingan.

Keberlanjutan program ini adalah adanya peningkatan kesadaran masyarakat untuk memperhatikan sanitasi lingkungan dan kebiasaan orang tua balita sehingga tidak terjadi kasus kecacingan pada balita yang dapat mengarah kepada kejadian stunting.

3. Menggunakan metode ceramah, diskusi dan tanya jawab untuk meningkatkan pengetahuan ibu balita tentang upaya pencegahan stunting ditinjau dari aspek kecukupan gizi, lingkungan dan pengelolaan keuangan keluarga. Tahapan persiapan meliputi diskusi internal tim untuk persiapan dan pembagian materi penyuluhan. Selain itu juga dilakukan persiapan seperti print out materi penyuluhan (brosur/ leaflet), persiapan LCD dan speaker, print out soal pre dan post test, persiapkan konsumsi. Tahapan pelaksanaan antara lain a). Persiapan lokasi mitra; b). Pembagian pre test; c). Pembagian brosur atau leflet; d). Penyampaian materi, e). Tanya jawab; f). Pembagian post test dan g). Pembagian konsumsi. Materi dibawakan secara bergantian oleh ketua tim (aspek lingkungan), 
dan anggota PKM (kecukupan gizi dan pendapatan). Partisipasi mitra dalam kegiatan ini adalah menyediakan tempat untuk penyuluhan, hadir dan aktif dalam penyampaian materi dan diskusi, mengisi form pre dan post test. Untuk mengevaluasi kegiatan penyuluhan akan dilakukan pre dan post test. Target yang ingin dicapai yaitu peningkatan pengetahuan ibu balita tentang upaya pencegahan stunting dengan skor 80 pada hasil post test/ ada peningkatan skor post test dibandingkan dengan pre test.
Keberlanjutan program ini dapat dilakukan melalui penyuluhan yang berkelanjutan yang dapat dilakukan oleh petugas puskesmas atau tim pengabdi, juga melalui pemasangan poster terkait pencegahan stunting pada masing - masing sector sehingga terus menjadi media edukasi bagi ibu balita.

\section{HASIL DAN PEMBAHASAN}

Kegiatan yang disepakati dengan mitra untuk mengatasi permasalahan mitra dapat dilihat pada tabel berikut :

Tabel 1. Kegiatan yang dilakukan dan Partisipasi Mitra

\begin{tabular}{|c|l|l|l|l|}
\hline No & \multicolumn{1}{|c|}{ Kegiatan } & \multicolumn{1}{c|}{ Metode } & \multicolumn{1}{c|}{ Partisipasi Mitra } & \multicolumn{1}{c|}{ Evaluasi } \\
\hline $\mathbf{1}$ & \multicolumn{1}{|c|}{$\mathbf{2}$} & \multicolumn{1}{c|}{$\mathbf{3}$} & \multicolumn{1}{c|}{$\mathbf{5}$} \\
\hline 1 & $\begin{array}{l}\text { Pemeriksaan } \\
\text { kualitas air bersih } \\
\text { yang digunakan } \\
\text { masyarakat }\end{array}$ & $\begin{array}{l}\text { Pemeriksaan } \\
\text { laboratorium } \\
\text { untuk } \\
\text { parameter fisik } \\
\text { dan } \\
\text { bakteriologi } \\
\text { air. }\end{array}$ & $\begin{array}{l}\text { Mengarahkan tim } \\
\text { PKM ke sumber air } \\
\text { yang digunakan di } \\
\text { masing - masing } \\
\text { sector }\end{array}$ & $\begin{array}{l}\text { Membandingkan } \\
\text { hasil pemeriksaan } \\
\text { kualitas air } \\
\text { dengan baku } \\
\text { mutu air bersih }\end{array}$ \\
\hline 2 & $\begin{array}{l}\text { Pemeriksan } \\
\text { Kecacingan pada } \\
\text { sampel feces } \\
\text { balita }\end{array}$ & $\begin{array}{l}\text { Pemeriksaan } \\
\text { kecacingan } \\
\text { pada balita } \\
\text { stunting }\end{array}$ & $\begin{array}{l}\text { Membantu dalam } \\
\text { pengambilan } \\
\text { sampel feses }\end{array}$ & $\begin{array}{l}\text { Positif dan negatif } \\
\text { telur cacing }\end{array}$ \\
\hline 3 & $\begin{array}{l}\text { Penyuluhan } \\
\text { stunting dan } \\
\text { pengelolaan } \\
\text { keuangan } \\
\text { keluarga }\end{array}$ & $\begin{array}{l}\text { Menyediakan lokasi } \\
\text { diskusi dan } \\
\text { Tanya jawab }\end{array}$ & Penyuluhan & Pre dan post test \\
\end{tabular}

Uraian masing - masing kegiatan program kemitraan masyarakat dapat sebagai berikut :

\section{Pemeriksaan Sampel Air}

Kegiatan pemeriksaan sampel air bersih bertujuan untuk mengetahui kualitas air bersih yang digunakan oleh keluarga dan adakah indikasi pencemaran yang dapat berdampak pada kejadian stunting 
pada balita. Kegiatan pengambilan sampel air melibatkan 2 orang dosen dan 2 orang petugas Puskesmas Perawatan Waai dan 1 mahasiswa Fakultas Kesehatan UKIM. Kegiatan berlangsung pada 15 Juli 2020. Jumlah sampel air yang diambil adalah sebanyak 6 sampel air untuk pemeriksaan fisik, kimia dan biologi air. Sumber air bersih yang digunakan oleh masyarakat Negeri Waai adalah air sungai, air sumur gali, air sumur bor dan air gunung (mata air). Air permukaan yang digunakan di Negeri Waai adalah Sungai Atua, Sungai Sasoi dan Air Gunung. Pengambilan sampel untuk parameter fisik dan kimia air diperlukan air sebanyak 1,5 Liter. Sedangkan untuk parameter biologi, pengambilan dilakukan secara aseptis untuk hindari kontaminasi dengan menggunakan botol steril yang disewa dari Laboratorium Kesehatan Provinsi Maluku.

Tim berangkat pada pukul 08.00 WIT dengan menggunakan 1 unit mobil yang juga mengangkut perlengkapan pengambilan sampel seperti botol steril, coolbag, botol bersih untuk sampel fisik dan kimia air dan perlengkapan lainnya. Sebelum berangkat, dilakukan pertemuan singkat dengan tim, untuk membicarakan pembagian tugas dan teknik pengambilan sampel di lapangan serta mempersiapkan persuratan yang dibutuhkan untuk perjalanan ke Maluku Tengah karena adanya pemberlakukan Pembatasan Sosial Berskala Besar (PSBB) di Kota Ambon. Setibanya di lokasi, tim berkoordinasi dengan kepala Puskesmas dan menyerahkan surat tugas. Kepala Puskesmas menginstruksikan 2 orang pegawai Puskesmas untuk bersama dengan tim, melakukan pengambilan sampel air. Kegiatan pengambilan sampel dimulai pada pukul 11.00 WIT dan dilakukan pengambilan sampel pada 6 sampel air yaitu 3 air sungai, 1 sumur gali, 1 air sumur bor, dan 1 mata air. Pengambilan sampel biologi dilakukan secara aseptis dan didinginkan di dalam coolbag dengan menggunakan icepack.
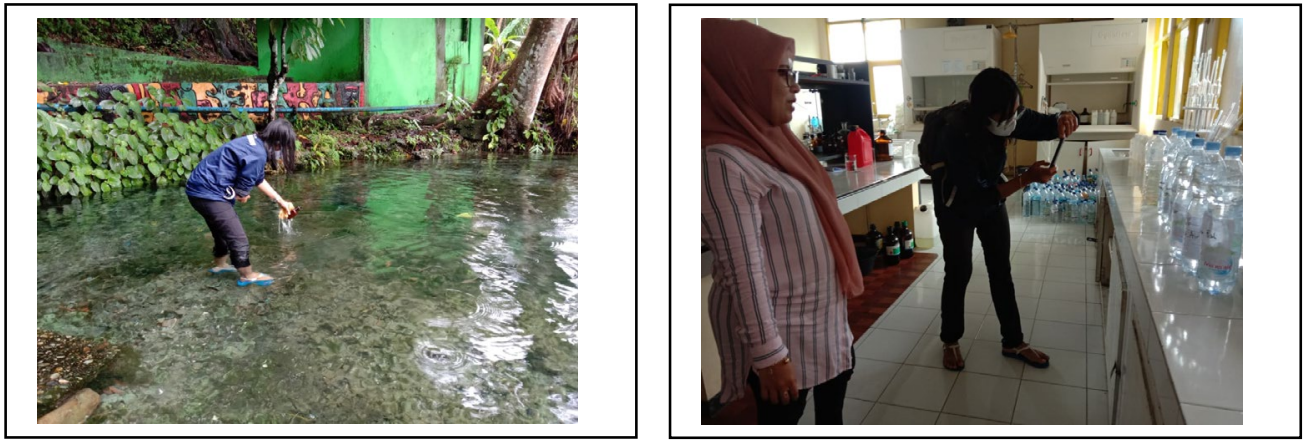

Gambar 3. Pengambilan Sampel Air dan Pemeriksaan di Laboratorium Kesehatan

Sampel air yang telah diambil langsung dibawa ke Balai Laboratorium Kesehatan dan Kalibrasi Alat Kesehatan Provinsi Maluku untuk diperiksa. Hasil pemeriksaan kualitas fisik air menunjukan bahwa parameter bau, TDS, kekeruhan, rasa, suhu dan warna, menunjukan masih memenuhi syarat sesuai Permenkes no 32 
tahun 2017 tentang Standar Baku Mutu Kesehatan Lingkungan dan Persyaratan Kesehatan Air Untuk Keperluan Higiene Sanitasi, Kolam Renang, Solus Per Aqua, dan Pemandian Umum. Hasil pemeriksaan kualitas kimia air menunjukan bahwa parameter flourida, nitrit, nitrat, sianida, besi, detergen, kesadahan, mangan dan $\mathrm{pH}$, menunjukan masih memenuhi syarat sesuai Permenkes no 32 tahun 2017 tentang Standar Baku Mutu Kesehatan Lingkungan dan Persyaratan Kesehatan Air Untuk Keperluan Higiene Sanitasi, Kolam Renang, Solus Per Aqua, dan Pemandian Umum. Sedangkan hasil pemeriksaan kualitas mikrobiologi air menunjukan bahwa parameter E. coli dan total coliform, menunjukan masih memenuhi syarat sesuai Permenkes no 416 tahun 1990 tentang Syarat-syarat dan Pengawasan Kualitas Air. Namun pada sampel 05 (sumur gali) dan 06 (sumur bor), tidak memenuhi syarat E.coli.

\section{Pemeriksaan Kecacingan}

Pemeriksaan kecacingan dilakukan untuk mengetahui ada tidaknya infeksi kecacingan pada balita akibat kurangnya perilaku hidup bersih dan sehat (PHBS) dari orang tua balita ketika memberi makan. Cacingan adalah penyakit yang disebabkan oleh infeksi cacing dalam tubuh manusia yang ditularkan melalui tanah. Pemeriksaan kecacingan pada balita, dilakukan pada hari Jumat, 17 Juli 2020, sebelumnya pada Kamis, 16 Juli 2020 telah dilakukan training kepada 4 kader posyandu untuk membantu pengambilan sampel feces dari rumah ke rumah, dikarenakan kondisi pandemic covid -19 (pemberlakuan PSBB).

Pelatihan yang diberikan kepada
kader adalah menjelaskan tujuan pengambilan dan cara pengambilan sampel feces yaitu pada pagi hari ketika akan dikumpulkan sehingga tidak merusak sampel. Selain itu kader posyandu juga mengumpulkan data dari orang tua balita tentang kebiasaan orang tua mencuci tangan sebelum siapkan dan saat beri makanan kepada anak; sumber air yang digunakan; pekerjaan orang tua; jumlah pendapatan; kebiasaan anak memasukan jari kedalam mulut dan konsumsi sayuran dan ikan pada balita yang sudah bisa makan. Jumlah sampel yang berhasil dikumpulkan adalah sebanyak 22 sampel. Sampel yang telah dikumpulkan langsung dibawa ke laboratorium untuk diperksa oleh analis. Tahapan pemeriksaan antara lain pengumpulan kotak sampel feces dari kader posyandu, persiapan alat dan bahan, perlakuan sampel, pemeriksaan mikroskopik, dan pencatatan hasil. Pemeriksaan kecacingan dilakukan pada pukul 12.00 WIT oleh analis kesehatan dengan beberapa langkah perlakuan sampel antara lain pembuatan apusan feses pada kaca slide dengan menggunakan tusuk gigi, selanjutnya diwarnai dengan eosin, tutup dengan deg glass, amati adanya telur cacing dan identifikasi jenisnya berdasarkan morfologi dengan pembesaran 10x atau 40x pada mikroskop. Hanya ada 26 sampel feces yang dikumpulkan karena ada balita yang belum buang air besar saat sampel hendak diambil. Hasil pemeriksaan menunjukan bahwa dari 26 sampel feses, ada 7 sampel yang positif telur cacing Ascaris lumbricoides. 

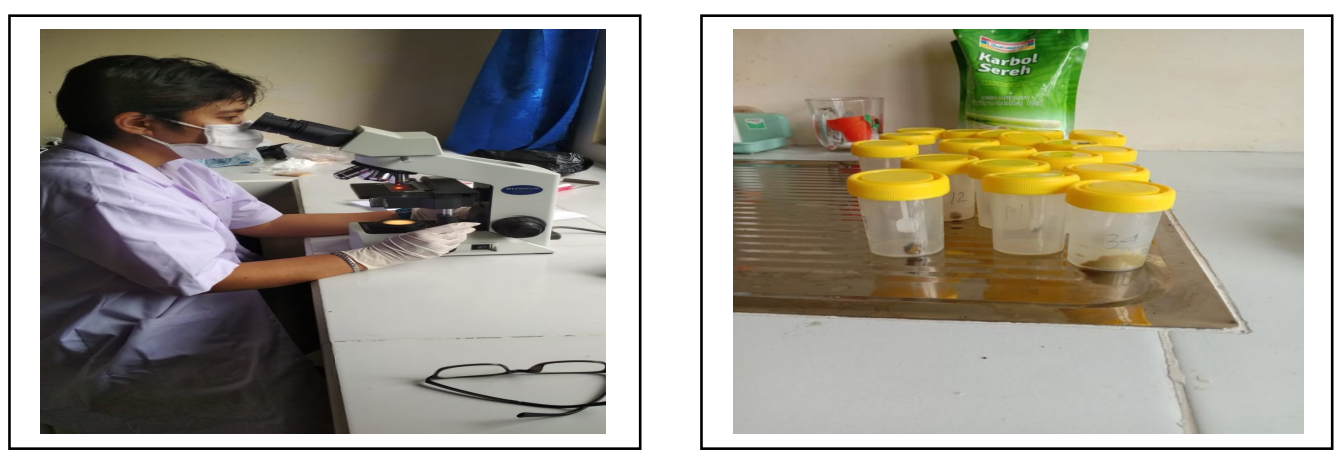

Gambar 4. Pemeriksaan Kecacingan

Hasil pendataan dari para kader posyandu yang mengumpulkan sampel feces, didapatkan beberapa informasi antara lain :

1. Kebiasaan orang tua mencuci tangan sebelum siapkan dan saat beri makan anak, dinyatakan" YA" oleh ke 26 responden. Artinya responden menyatakan bahwa terbiasa mencuci tangan sebelum siapkan dan saat beri makan anak.

2. Sumber air yang digunakan antara lain air hujan sebanyak 7 responden, air gunung (mata air) sebanyak 15 responden; air gallon sebanyak 2 responden dan air sumur sebanyak 2 responden.

3. Jumlah pendapatan berkisar antara Rp. 100.000 - Rp. 900.000, dengan jenis pekerjaaan adalah petani, ojek, nelayan, dan buruh kasar.

4. Kebiasaan anak memasukan jari ke mulut, sebanyak 16 responden yang menyatakan "YA" dan sebanyak 10 responden yang menyatakan "TIDAK".

5. Kebiasaan konsumsi sayur dan ikan, sebanyak 6 responden menyatakan "TIDAK" terbiasa konsumsi sayur dan ikan; sedangkan 20 responden menyatakan "YA".

Kecacingan banyak ditemukan di daerah dengan kelembaban tinggi terutama pada kelompok masyarakat dengan kebersihan diri dan sanitasi lingkungan yang kurang baik. Salah satu penyakit kecacingan adalah penyakit cacing usus yang ditularkan melalui tanah atau soil transmitted helmints. Jenis cacing yang terpenting adalah cacing gelang (Ascaris lumbricoides), cacing tambang (Ancylostoma duodenale), Necator americanus, dan cacing cambuk (Trichuris trichiura). Factor - factor risiko yang yang berpengaruh terhadap terjadinya infeksi cacing tambang adalah factor karakteristik (umur, jenis kelamin, imunitas), factor lingkungan fisik (tekstur tanah, kelembaban tanah, adanya lahan pertanian/ kebun, kondisi sanitasi sekolah dan rumah), factor biologis (keberadaan cacing tambang pada kotoran anjing atau kucing atau tanah), factor sosial ekonomi (pekerjaan, pendidikan, penghasilan), factor budaya (pelihara anjing, kucing, bermain tanpa alas kaki, defekasi sembarang tempat), dan factor lain yaitu ada tidaknya program pemberantasan 
penyakit kecacingan pada anak sekolah (Bisara, 2014).

Untuk memelihara kesehatan dan mencegah kecacingan, dapat dilakukan upaya promosi kesehatan untuk meningkatkan perilaku hidup bersih dan sehat melalui media cetak maupun elektronik, penyuluhan langsung, bimbingan dan konseling, intervensi perubahan perilaku, dan pelatihan. Perilaku hidup bersih dan sehat dilakukan melalui cuci tangan pakai sabun, menggunakan air bersih untuk keperluan rumah tangga, menjaga kebersihan dan keamanan makanan, menggunakan jamban sehat, dan mengupayakan kondisi lingkungan yang sehat (Permenkes RI No 15 Tahun 2017, tentang Penanggulangan Cacingan).

\section{Penyuluhan Stunting dan Pengelolaan Keuangan Keluarga}

Penyuluhan stunting dan pengelolaan keuangan keluarga dilakukan dengan tujuan meningkatnya pengetahuan ibu balita tentang apa itu stunting, dampak, penyebab, dam pencegahan stunting serta pengelolaan keuangan keluarga yang baik. Kegiatan penyuluhan dilakukan di 2 lokasi, pada tanggal 16 Agustus 2020, dan dihadiri oleh 33 ibu balita. Tahapan kegiatan penyuluhan antara lain: persiapan tim yang meliputi cetak leaflet, pembuatan pre dan post test, beli buku catatan keuangan, belanja alat dan bahan untuk protocol pencegahan covid (masker, sabun cuci tangan, wadah untuk air mengalir), cetak spanduk serta koordinasi dengan mitra untuk menyiapkan tempat untuk penyuluhan. Pelaksanaan di lokasi meliputi pengisian daftar hadir, menjawab pre test, penyuluhan oleh tim pengabdi. Tahapan evaluasi juga dilakukan dengan pengisian post test oleh ibu balita. Target yang ingin dicapai yaitu peningkatan pengetahuan ibu balita tentang upaya pencegahan stunting dengan skor 80 pada hasil post test/ ada peningkatan skor post test dibandingkan dengan pre test. Hasil pre dan post test dapat dilihat pada tabel berikut :

Tabel 2. Hasil Tingkat Pengetahuan Ibu Balita tentang stunting

\begin{tabular}{|c|c|c|c|c|c|c|c|c|}
\hline \multirow{2}{*}{ Kategori Nilai } & \multicolumn{4}{|c|}{ Pretest } & \multicolumn{4}{c|}{ Posttest } \\
\cline { 2 - 9 } & n & \% & Mean & Median & n & \% & Mean & Median \\
\hline Cukup $(<80)$ & 25 & 76 & \multirow{2}{*}{64,2} & 60 & 5 & 15 & \multirow{2}{*}{64,8} & 80 \\
\hline Baik $(\geq 80)$ & 8 & 24 & & 28 & 85 & 84 & \\
\hline
\end{tabular}

Tabel 3.2 menunjukan jumlah ibu balita dengan kategori nilai baik $(\geq 80)$ meningkat pada posttest dibandingkan pretest, yaitu dari $24 \%$ pada pretest meningkat menjadi $85 \%$ pada posttest. Selain itu, nilai mean dan median pada posttest pun menunjukan adanya peningkatan dibandingkan dengan pretest. Hal ini menunjukan bahwa terjadi peningkatan pengetahuan pada ibu balita setelah diberikan penyuluhan dengan menggunakan metode ceramah dan media leaflet. 
Tabel 3. Hasil Tingkat Pengetahuan Ibu Balita tentang Pengelolaan Keuangan Keluarga

\begin{tabular}{|c|c|c|c|c|c|c|c|c|}
\hline \multirow{2}{*}{ Kategori Nilai } & \multicolumn{4}{|c|}{ Pretest } & \multicolumn{4}{|c|}{ Posttest } \\
\cline { 2 - 7 } & n & \% & Mean & Median & n & \% & Mean & Median \\
\hline Cukup $(<75)$ & 18 & 55 & \multirow{2}{*}{62} & 50 & 1 & 3 & 90 & 100 \\
\hline Baik $(\geq 75)$ & 15 & 45 & & & 32 & 97 & 90 & \\
\hline
\end{tabular}

Tabel 3.3 menunjukan jumlah ibu balita dengan kategori nilai baik $(\geq 75)$ meningkat pada posttest dibandingkan pretest, yaitu dari $45 \%$ pada pretest meningkat menjadi $97 \%$ pada posttest. Selain itu, nilai mean dan median pada posttest pun menunjukan adanya peningkatan dibandingkan dengan pretest. Hal ini menunjukan bahwa terjadi peningkatan pengetahuan pada ibu balita setelah diberikan penyuluhan dengan menggunakan metode ceramah dan media leaflet.

\section{KESIMPULAN}

Kesimpulan dari program kemitraan kepada masyarakat bagi ibu dan balita di Puskesmas Perawatan Waai antara lain :

1. Pemeriksaan 6 sampel air bersih telah dilakukan dan hasilnya masih memenuhi persyaratan fisik dan kimia air, namun ada persyaratan mikrobiologi, masih ada 2 sampel yang ditemukan keberadaan E.coli melebihi ambang batas.

2. Pemeriksaan kecacingan menunjukan bahwa dari 26 sampel feses, ada 7 sampel yang positif telur cacing Ascaris lumbricoides. Kebiasaan anak memasukan jari ke mulut, sebanyak 16 responden yang menyatakan "YA", sedangkan kebiasaan konsumsi sayur dan ikan, sebanyak 6 responden menyatakan
"TIDAK" terbiasa konsumsi sayur dan ikan.

3. Ada peningkatan pengetahuan ibu balita, yang ditunjukan dengan peningkatan nilai rata - rata dan nilai media pada pre dan post test.

\section{REFERENSI}

Aridiyah Farah, Rohmawati Ninna, Ririanty Mury. 2015. Faktor yang Mempengaruhi Kejadian Stunting pada Anak Balita di Wilayah Pedesaan dan Perkotaan. E-jornla Pustaka Kesehtan. Vol 3 (1) 163 - 170.

Badan Pusat Statistik. 2018. Kecamatan Salahutu dalam Angka. BPS Maluku Tengah.CV. Aman Jaya.

Febrindari A. P, Nuryanto. 2016. Hubungan Asupan Energi, Protein, Seng dan Kejadian Infeksi Kecacingan Status Gizi Anak Umur 12 - 36 Bulan. Journal of Nutrition College. Vol 5(4) : $353-359$.

Ibrahim Irviani, Faramita Ratih. 2014. Hubungan Faktor Sosial Ekonomi Keluarga dengan Kejadian Stunting Anak usia 24 59 Bulan di Wilayah Kerja Puskesmas Barombong Kota Makassar Tahun 2014. Al-sihah Public Health Science Journal. Vol 7(1): 63-7 
Kementerian Desa Pembangunan Daerah Tertinggal dan Transmigrasi. 2017. Buku Saku Desa dalam Penanganan Stunting. Kementerian Desa: Jakarta.

Mugianti Sri, Mulyadi Arif, Anam Agus, Najah Zian. 2018. Faktor Penyebab Anak Stunting Usia 25-60 Bulan di Kecamatan Sukorejo Kota Blitar. Jurnal Ners dan Kebidanan. Vol 5(2) : $268-$ 278

Nadiyah, Briawan Dodik, Martianto Drajat. 2014. Faktor Risiko Stunting Pada Anak Usia 0 - 23 Bulan di Provinsi Bali, Jawa Barat dan Nusa Tenggara Timur. Jurnal Gizi dan Pangan. Vol 9 (2) : $125-132$.

Ni'mah K, Nadhiroh S. T. 2015. Faktor yang Berhubungan dengan Kejadian Stunting pada Balita. Media Gizi Indonesia. 10 (1) : 13 $-19$.

Setiawan Eko, Machmud Rizanda, Masrul.2018. Faktor - Faktor yang Berhubungan dengan Kejadian Stunting pada Anak Usia 24 - 59 Bulan di Wilayah Kerja Puskesmas Andalas Kecamatan Padang Timur Kota Padang Tahun 2018. Jurnal
Kesehatan Andalas. Vol 7(2) : 275-284.

Sutarto, Mayasari Dian, Indriyani Reni. 2018. Stunting, Faktor Risiko dan Pencegahannya. $J$ Agromedicine. Vol 5 (1) : 540 545.

Souisa Gracia, Lawalata I.V, Titaley S, Talarima B. 2018. Peningkatan Perilaku Hidup Bersih dan Sehat (PHBS) pada Pendidik dan Peserta Didik di Kecamatan Leihitu Barat Kabupaten Maluku Tengah. Jurnal Pengabdian Kepada Masyarakat. Vol 24(3) : $747-754$

Tim Nasional Percepatan Penanggulangan Kemiskinan. 2017. 100 Kabupaten/ Kota Prioritas untuk Intervensi Anak Kerdil (Stunting). Sekertariat Wakil Presiden RI. Jakarta.

Wahdah S, Juffri M, Huriyati E. 2015. Faktor Risiko Kejadian Stunting pada anak Umur 6 - 36 bulan di Wilayah Pedalaman Kecamatan Silat Hulu, Kapuas Hulu, Kalimantan Barat. Jurnal Gizi dan dietetic Indonesia. Vol 3(2): $119-130$ 